\title{
THE RELATION BETWEEN THE BLOOD UREA CONCENTRATION AND THE AMOUNT OF FUNCTIONING RENAL TISSUE ${ }^{1}$
}

\author{
By EATON M. MACKAY aND LOIS LOCKARD MACKAY
}

(From the Department of Medicine of Stanford University Medical School, San Francisco, California)

(Received for publication November 19, 1927)

The concentration of urea in the blood is dependent upon the rate of urea formation and the rate of urea excretion. Urea formation varies with the protein content of the diet and with the rate of protein metabolism while the rate of urea excretion is influenced by many factors (1). As a result the blood urea concentration normally fluctuates through a considerable range of variation. However, unless under exceptional circumstances, the upper limit attained is comparatively low so long as there is no reduction in the amount of functioning renal tissue. The marked increases in the concentration of urea in the blood which are seen in the terminal stages of Bright's disease when the amount of functioning renal tissue is presumably greatly reduced occur too often to require comment but concerning the degree to which the amount of renal tissue must be reduced before an increase in the blood urea concentration over the normal limits ensues nothing definite is known. It is even questionable whether the transient increase in the blood urea concentration which follows the removal by operation of half of the renal tissue of the body (2) can be ascribed to the reduction in kidney substance. Such an increase might well be a result of an acceleration of protein catabolism and might occur after any sufficiently severe operative procedure. In an attempt to throw some light on these questions a study has been made in a group of patients of the relation between the degree of reduction in the amount of functioning renal tissue and the degree of increase in blood urea concentration.

1 This work was aided by the Wellington Gregg Fund for the Investigation of Bright's Disease. 


\section{METHODS}

The blood urea concentration was determined in each case on a freshly drawn specimen of venous blood obtained not more than two days before the procedure to determine the amount of functioning renal tissue. It was necessary that only a short time should elapse between the two observations, for in some cases the blood urea concentration was increasing rather rapidly. Another necessary precaution was that the urea determination should precede and not follow the estimation of the functioning kidney tissue because in most cases urea was administered in this test and there was always the possibility that the blood urea would be higher than usual for several days. The blood urea estimation was carried out according to Addis' method (3).

The amount of functioning renal tissue was determined in each patient according to the procedure described by Addis (4). It is briefly as follows: At 6 a.m. on the morning of the test the patient slowly drinks about $1000 \mathrm{cc}$. of water in which urea is dissolved. In those instances where the blood urea concentration is between 15 and $25 \mathrm{mgm}$. per $100 \mathrm{cc}$. of blood 15 to 20 grams of urea are given. If the blood concentration is already as high as $70 \mathrm{mgm}$. urea per $100 \mathrm{cc}$. of blood no urea need be taken. At intermediate blood urea levels appropriate quantities of urea are administered, so that when the first blood is collected it should have a concentration of between 60 and $90 \mathrm{mgm}$. of urea per $100 \mathrm{cc}$. of blood. At $7 \mathrm{a} . \mathrm{m}$. and every hour thereafter until and including 11 a.m. the patient drinks two glasses $(600 \mathrm{cc}$.) of water. No breakfast is given. Urine is voided every hour, but at 9 a.m. the time at which urination is completed is noted to within thirty seconds and at 10 a.m., 11 a.m. and 12 noon urine is passed directly into special bottles and the exact time noted. The patient is instructed to make each voiding as complete as possible, and the time is taken at the end, and not at the beginning, of urination. For women a special commode is used with a large funnel emptying into a removable bottle. A blood specimen is obtained at exactly the middle of each of the three hourly periods over which urine is collected. Beginning with the first urine collection at 9 a.m. the entire procedure is carried out in the laboratory. A high degree of 
accuracy in the timing of the blood and urine collections is necessary. The methods (3) used for determining the urea concentration of the blood and urine have proven themselves to be particularly applicable to a test of this nature.

Under the conditions which have been described the rate of urea excretion is usually governed by only two factors, the concentration of urea in the blood (5) and the amount of secreting tissue in the kidney (6). The ratio, $\frac{\text { urea in one hour's urine }}{\text { urea in } 100 \mathrm{cc} \text {. blood }}$, is then a measure of the amount of secreting tissue in the kidney. After correction for the

TABLE 1

\begin{tabular}{|c|c|c|}
\hline Clinical diagnosis & $\begin{array}{l}\text { Number of } \\
\text { cases }\end{array}$ & $\begin{array}{l}\text { Number of } \\
\text { observations }\end{array}$ \\
\hline \multicolumn{3}{|l|}{ Hemorrhagic Bright's disease: } \\
\hline Initial stage $\ldots \ldots \ldots \ldots \ldots \ldots$ & 3 & 5 \\
\hline Latent stage . . . . . . . . & 10 & 13 \\
\hline Active stage . . . . . . . . . . . . & 22 & 30 \\
\hline Terminal stage $\ldots \ldots \ldots \ldots \ldots \ldots \ldots \ldots \ldots$ & 10 & 15 \\
\hline \multicolumn{3}{|l|}{ Degenerative Bright's disease: } \\
\hline Cryptic ................... & 10 & 18 \\
\hline Bacterial............. & 2 & 3 \\
\hline Arteriosclerotic Bright's disease $\ldots \ldots \ldots \ldots \ldots \ldots$ & 8 & 8 \\
\hline \multicolumn{3}{|l|}{ Miscellaneous: } \\
\hline Polycystic kidneys. & 2 & 2 \\
\hline Pyonephrosis.............. & 1 & 1 \\
\hline Orthostatic albuminuria $\ldots \ldots \ldots \ldots \ldots$ & 2 & 2 \\
\hline Single kidney $\ldots \ldots \ldots \ldots \ldots \ldots \ldots \ldots$ & 1 & 1 \\
\hline
\end{tabular}

theoretical body surface corresponding to an individual's height and age this ratio is expressed as a percentage of an average ratio determined on a large group of normal individuals and corrected to their body surface. The final figure thus obtained expresses that percentage which the functioning tissue that they possess is of the expected normal amount.

When the procedure which has been described is properly carried out with the necessary attention to detail the amount of renal tissue found for a normal individual is very close to that which would be expected (7) from the sex, age, and body weight. By weighing the kidneys of rabbits after the completion of this test it has been shown 
that the actual amount of functioning renal tissue varies in direct proportion to the magnitude of the ratio (8). If on the other hand the procedure detailed above is not strictly adhered to one may easily conclude as Stander, Duncan and Moses (9) have, that this ratio

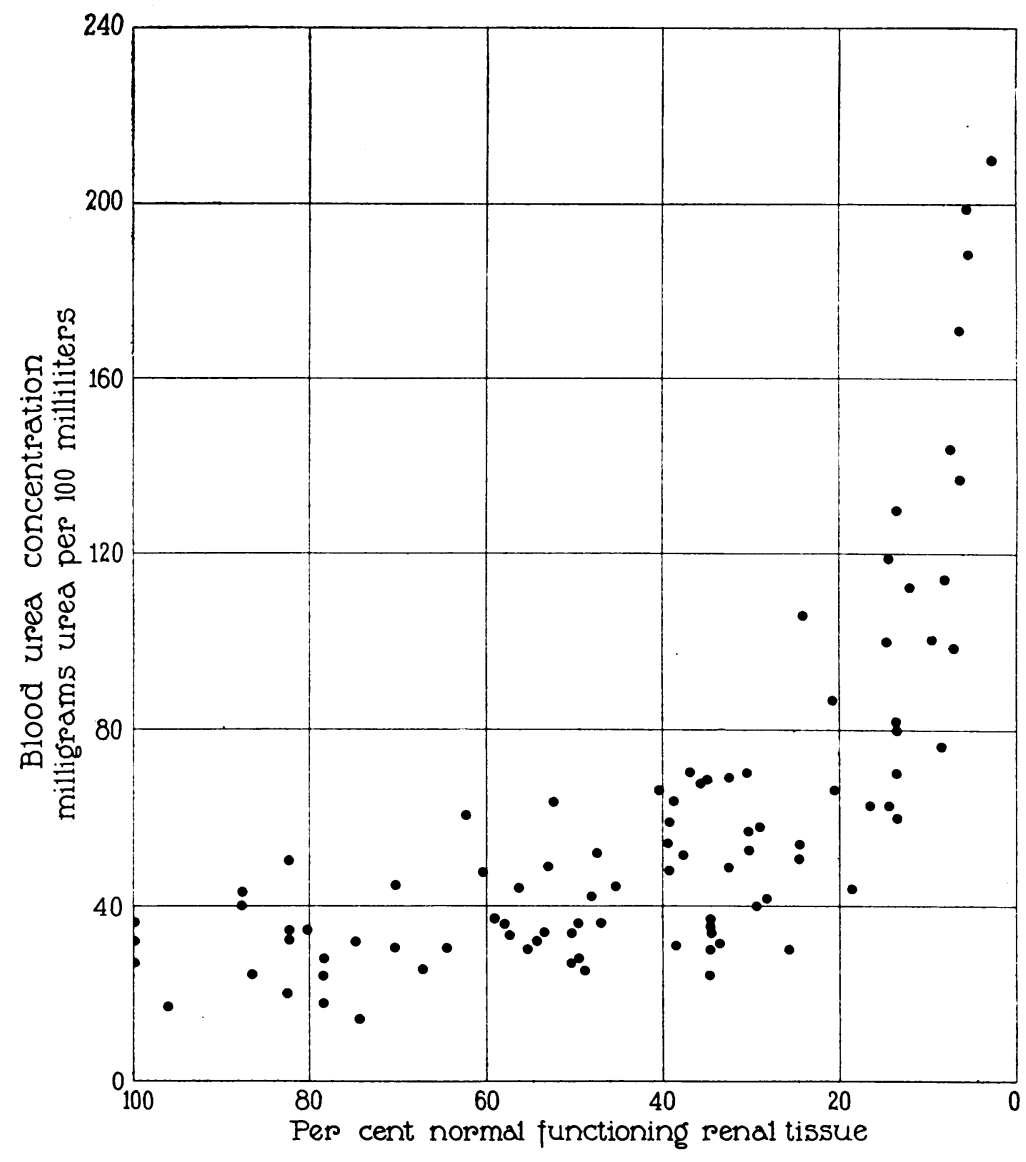

Fig. 1

"varies between wide limits" and shows a "lack of uniformity in the values" obtained. In this instance since neither water nor urea were administered the authors failed to observe the essential condition of the test, that the kidney should be placed under circumstances which call for great activity in urea excretion. They made only a single 
observation and even its accuracy is doubtful for the urine collections were left to nurses, a procedure quite out of the question in quantitas tive work of this nature.

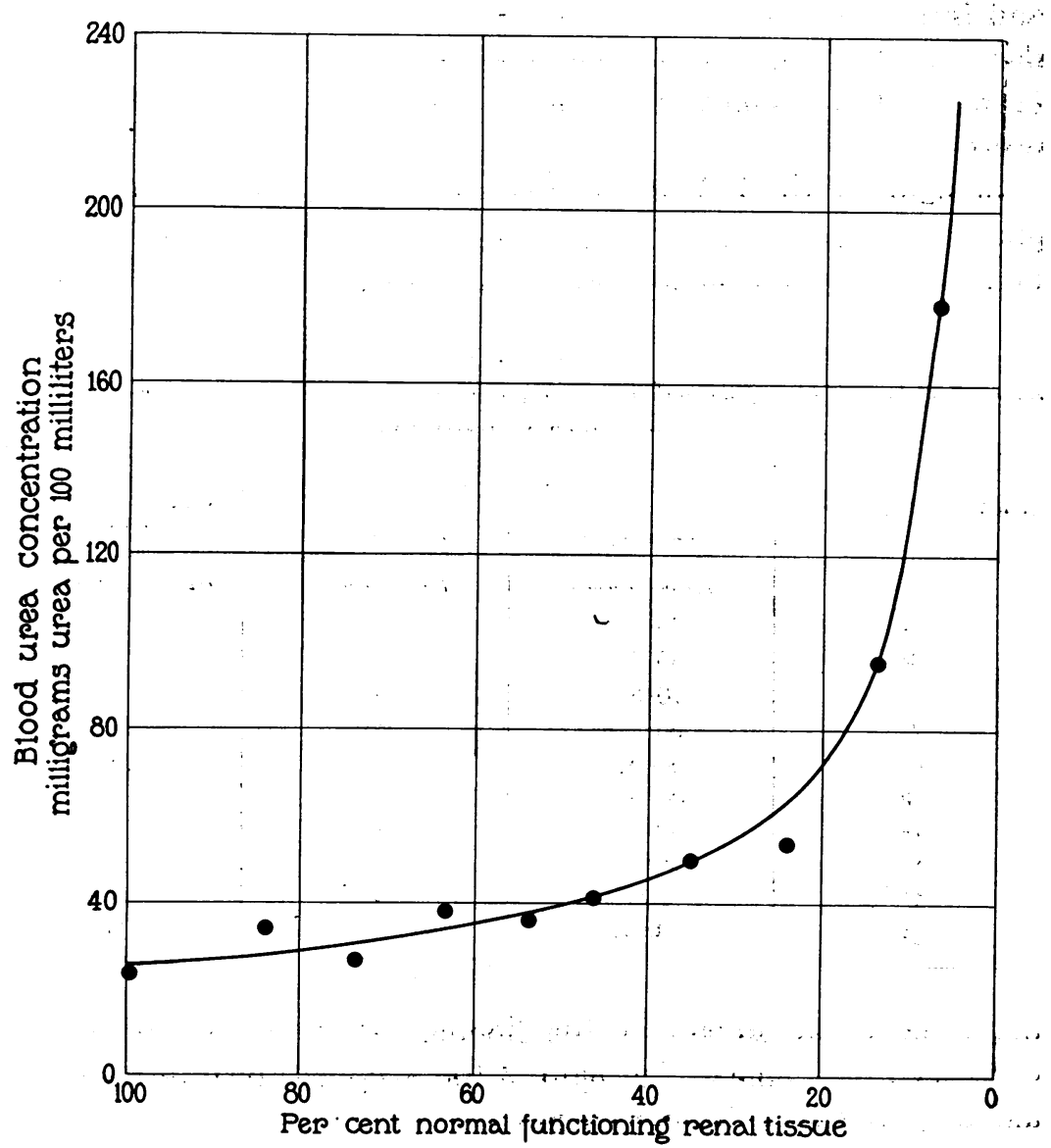

Fig. 2

\section{RESULTS}

The distribution of the cases from which observations both of the blood urea concentration and of the amount of active kidney tissue were obtained is given in table 1. Practically all of them were indi- 
viduals suffering from Bright's disease and of these the majority were in some stage of the hemorrhagic type. The higher blood urea observations were all from the two individuals with polycystic kidneys and from the groups with active and terminal hemorrhagic Bright's disease. The only observations excluded are those from a few patients in whom the administration of urea and water failed to produce diuresis.

In figure 1 the individual blood urea concentrations have been plotted against the percentage of still functioning renal tissue. In table 2 these observations have been arranged in a series of classes

TABLE 2

Averages of the per cent of normal functioning renal tissue and of blood urea concentrations. Data from all observations

\begin{tabular}{|c|c|c|c|}
\hline \multirow{2}{*}{ Number of observations } & \multicolumn{2}{|c|}{ Functioning renal tissue } & \multirow{2}{*}{$\begin{array}{l}\text { Blood urea } \\
\text { concentration-mean } \\
\text { for class }\end{array}$} \\
\hline & Limits of class & Mean for class & \\
\hline & per cent normal & per cent normal & mgm. per 100 cc. blood \\
\hline 4 & $90-100$ & 99 & 27 \\
\hline 9 & $80-90$ & 83 & 35 \\
\hline 7 & $70-80$ & 74 & 29 \\
\hline 4 & $60-70 \ldots$ & 63 & 38 \\
\hline 14 & $50-60$ & 54 & 36 \\
\hline 8 & $40-50$ & 46 & 51 \\
\hline 18 & $30-40$ & 35 & 50 \\
\hline 13 & $20-30$ & 24 & 55 \\
\hline 12 & 10-20. & 14 & 95 \\
\hline 11 & $0-10$ & 6 & 179 \\
\hline
\end{tabular}

according to the amount of functioning tissue and the averages of each class determined. In figure 2 the averages have been charted and a curve drawn through them.

\section{CONCLUSIONS}

It is evident from the above data that the blood urea concentration increases slightly with any reduction from the normal amount of functioning renal tissue but does not begit to rise markedly until the Eidneys are reduced to less than half of their original size. Beyond this point the blood urea concentration rises with increasing rapidity to higher and higher levels as the amount of renal tissue is still further 
decreased. The interesting fact is brought out that a patient with Bright's disease may have a blood urea concentration which is within the limits of normal even though only 50 per cent of the normal amount of functioning renal tissue remains.

\section{SUMMARY}

The relation between the degree of reduction in the amount of functioning renal tissue and the degree of increase in the blood urea concentration was determined in a group of patients who had a reduction in their functioning renal tissue. Practically all of them were individuals suffering from Bright's disease.

The blood urea concentration does not begin to rise markedly until the active kidney tissue is reduced to about half of its original amount.

The blood urea concentration becomes higher and higher with increasing rapidity as the amount of functioning renal tissue is still further decreased.

\section{BIBLIOGRAPHY}

1. Addis, T., and Drury, D. R., Jour. Biol. Chem., 1923, lv, 629. The Rate of Urea Excretion. VII. The Effect of Various Other Factors than Blood Urea Concentration on the Rate of Urea Excretion.

2. Karsner, H. T., Bunker, H. A., Jr., and Grabfield, G. P., Jour. Exper. Med., 1915, xxii, 544. A Note on the Immediate Effects of Reduction of Kidney Substance.

3. Addis, T., Jour. Lab. and Clin. Med., 1924, x, 402. Urea Determinations in Blood and Urine.

4. Addis, T., Arch. Int. Med., 1922, xxx, 378. Renal Function and the Amount of Functioning Tissue.

5. Addis, T., and Drury, D. R., Jour. Biol. Chem., 1923, lv, 105. The Rate of Urea Excretion. V. The Effect of Changes in Blood Urea Concentration on the Rate of Urea Excretion.

6. Addis, T., Myers, B. A., and Oliver, Jean, Arch. Int. Med., 1924, xxxiv, 243. The Regulation of Renal Activity. IX. The Effect of Unilateral Nephrectomy on the Function and Structure of the Remaining Kidney.

7. Vierordt, H., Anatomische Physiologische und Physikalische Daten und Tabellen. Jena 1906, 3rd Aufl. p. 36.

8. Taylor, F. B., Drury, D. R., and Addis, T., Am. Jour. Physiol., 1923, lxv, 55. The Regulation of Renal Activity. VIII. The Relation between the Rate of Urea Excretion and the Size of the Kidneys.

9. Stander, H. J., Duncan, E. E., and Moses, B. L., Bull. Johns Hopkins Hospital, 1924, xxxv, 97. The Excretion Rate of Urea in the Toxemias of Pregnancy. 